\title{
RESEARCH
}

Open Access

\section{Prevalence and determinants of pre-adolescent (5-14 years) acute and chronic undernutrition in Lay Armachiho District, Ethiopia}

Eleni Belay ${ }^{1}$, Simegnew Handebo ${ }^{2}$, Terefe Derso ${ }^{3}$, Amare Tariku $^{3}$ and Mekonnen Sisay ${ }^{3 *}$

\begin{abstract}
Background: In Ethiopia it is documented that $16 \%$ of all grade repetitions in primary school and $33.9 \%$ childhood deaths are associated with undernutrition. School aged children are often omitted from public health research. Thus, the present study was carried out to find out the prevalence and determinants of pre-adolescent (5-14 years) acute and chronic undernutrition in Lay Armachiho District.

Methods: In this community based cross-sectional study, anthropometrics, individual and household characteristics data were collected from December, 2016 to January, 2017. A total of 848 school aged children (5-14 years) were included in the study. Z-scores for height-for-age (HAZ) and body-mass-index-for-age (BAZ) were calculated to illustrate stunting (chronic undernutrition) and thinness (acute undernutrition), respectively with Anthro Plus software version 1.0.4 using the WHO 2007 growth reference standard. Finally, backward stepwise multivariable logistic regression analysis was carried out to identify factors associated with stunting and thinness, individually.

Results: The overall prevalence of stunting and thinness was 35.5 and 9.9\%, respectively. The multivariable analysis showed that child age 10-14 years $[A O R=1.58,95 \% \mathrm{Cl}: 1.17,2.12]$ and lack of availability of a latrine at home $[A O R=1.60 ; 95 \% \mathrm{Cl}: 1.17,2.20)]$ were associated with increased likelihood of stunting. Nevertheless, child's hand washing practice before eating $[A O R=0.67 ; 95 \% \mathrm{Cl}: 0.49,0.91]$ was protective against stunting. Children who consumed diversified foods $[A O R=0.64 ; 95 \% \mathrm{Cl} 0.39,0.97]$ were protected from thinness.

Conclusion: In Lay Armachiho district, one-third and one in every ten of school aged children were stunted and thin, respectively. Children age 10-14 years, lack of availability of a latrine at home and hand washing practices before eating were associated with stunting, while only dietary diversity was associated with thinness. Ensuring consistent hand washing practices before eating and ensuring availability of latrine should be improved in the region, which can assist in effectively tackling undernutrition. Finally, dietary diversification should be enhanced to rectify burden of acute undernutrition.
\end{abstract}

Keywords: Stunting, Thinness, School aged children, Ethiopia

\footnotetext{
* Correspondence: mekudesu@gmail.com

${ }^{3}$ Department of Human Nutrition, Institute of Public Health, College of

Medicine and Health Sciences, University of Gondar, Gondar, Ethiopia

Full list of author information is available at the end of the article
}

(c) The Author(s). 2019 Open Access This article is distributed under the terms of the Creative Commons Attribution 4.0 International License (http://creativecommons.org/licenses/by/4.0/), which permits unrestricted use, distribution, and reproduction in any medium, provided you give appropriate credit to the original author(s) and the source, provide a link to the Creative Commons license, and indicate if changes were made. The Creative Commons Public Domain Dedication waiver (http://creativecommons.org/publicdomain/zero/1.0/) applies to the data made available in this article, unless otherwise stated. 


\section{Background}

Child survival, protection and development are the prerequisite for the future development of the nations' [1]. It is important to ensure optimal child growth and development in order to significantly accelerate economic development of nations [2]. The nutritional status of children is an index of the national investment in the development of future man power; this indicates the changing trend of the nutritional profile of a region [3, 4]. The main nutritional problems facing school aged children are having a low $(<-2$ SD) body mass index for their respective age (BAZ)) (acute malnutrition) and low $((<-2 \mathrm{SD}))$ height-for-age (HAZ) (stunting) [5, 6].

Stunting in school aged children is associated with poor nutrition in the early childhood years and the degree of stunting tends to increase throughout the school-aged years [7, 8]. However, children can exhibit improvement in their growth and development if their environment improves [9]. Therefore, interventions in school-aged children help to complement efforts in the preschool years to reduce levels of stunting and its related effects on children's health and education [8].

However, globally malnutrition continues to be a primary cause of poor health and mortality among school aged children particularly in resource limited countries [4, 5]. More than 200 million school aged children are stunted and thin, and unless immediate action is taken, about one billion school aged children will be growing up by 2020 with compromised physical and mental development [9]. In Ethiopia studies conducted in Durbete Town and Addis Ababa city reported that 11.2 and $19.6 \%$ of school aged children are stunted $[10,11]$.

Under-nutrition correlates with decreased ability to fight off infection and poor school performance in children. In addition, undernutrition impaired productivity and earnings during their later life, adulthood period [12-15].

Several studies had identified factors associated with stunting in school-aged children include: male sex, older age group, higher birth order, large family size, low meal frequency, fever, minimal poultry consumption, skipping breakfast, children whose mothers are working, household food insecurity, children who had an unemployed father, and children whose mother had limited education $[10,11,16-21]$. Few studies elicited the correlates of acute undernutrition; having large number of children living the house, unemployed father and inadequate intake of food was associated with being acutely undernourished [16, 17, 21]. However, consumption of animal protein and having a literate household head protected children from acute undernutrition [16].

In Ethiopia, 16 and 34\% primary school repetitions and under five mortality respectively were associated with stunting $[22,23]$. In spite of this fact, public health interventions do not pay much attention to school aged and adolescents [15].

The majority of the former local studies [24-26] focused on investigating the problem among under five children. There is no previous study conducted regarding the magnitude of acute and chronic undernutrition among preadolescent groups in Lay Armchiho districts. Thus, to fill the knowledge gap, we intended to study stunting, thinness and associated factors among school aged children (5 to 14 years) in Lay Armachiho districts. The findings of this study will help to inform decision for policy and practice.

\section{Methods}

\section{Study setting and design}

A community based cross-sectional study was carried out from December, 2016 to January, 2017 in Lay Armachiho District situated in Amhara region, Ethiopia. Based on the 2007 national census conducted by the Central Statistical Agency of Ethiopia [27], this district has a total population of 157,836 [28]. The district is divided in 26 kebeles (The smallest administration unit in Ethiopia). This region primarily relies on farming to sustain their livelihood.

\section{Study population and sample size determination}

All school-aged (5-14 years) children who lived in the district for at least 6 months were recruited into the study. A single population proportion formula $\left(\mathbf{n}=\left(Z_{\mathrm{a} / \mathbf{2}}\right)^{\mathbf{2}} \mathbf{P}(\mathbf{1}-\mathbf{P}) /\right.$ $\mathbf{d}^{2}$ ) was used to calculate sample size taking into account of the following assumptions; $42.7 \%$ as prevalence $(\mathrm{P})$ of stunting in Libo Kemkem District, Ethiopia [16], 95\% level of confidence $\left(\mathrm{Z}_{\mathrm{a} / 2}\right)^{2}, 5 \%$ margin of error $\left(\mathrm{d}^{2}\right)$ and a design effect of 2 . Finally, a $15 \%$ non-response rate was also added to get the sample size of 869 .

A multi-stage sampling was applied to select the samples. Five kebeles were selected out of 26 Kebeles by lottery method. The households with school-aged children in each selected kebele were obtained from the administration offices or from health extension workers of the kebeles. The sample size was distributed to each kebele in proportion to the number of children in each kebele. Systematic sampling technique was carried out after identifying an initial household by lottery method. In addition, if more than one study participant was found in the household, the lottery method was used to select a single study participant.

\section{Data collection procedures}

The structured questionnaire consisted of socio-demographic, health status, dietary practices, and households' characteristics, and was used to collect the data. The $24 \mathrm{~h}$ recall method was used to obtain food consumed in the previous $24 \mathrm{~h}$ preceding the survey. 
Anthropometric data (height and weight) was taken from school-aged children by adhering to the specific standards $[29,30]$. Weight was measured to the nearest $0.1 \mathrm{~kg}$ with an electronic scale (Seca, $881 \mathrm{U}$, Germany). Child height was measured to the nearest $0.1 \mathrm{~cm}$ using a wooden stadiometer placed on a flat surface. The child stood on the basal part of the device with feet together, without shoes and touched the back of the head, shoulders, buttocks and the heels to the vertical measuring board. Five supervisors and ten data collectors were involved in this study. Intensive training was given to data collectors and supervisors on how to conduct anthropometry measurement and interview techniques by the primary investigator. The questionnaire was pretested. After little modification, it was administered in Amharic, the local language.

\section{Study variables}

Nutritional status of children was assessed using anthropometric indicators, Height-for-Age (HAZ) and Body Mass Index for age (BAZ). Consequently, children having $\mathrm{HAZ}<-2 \mathrm{SD}$ and $\mathrm{BAZ}<-2 \mathrm{SD}$ were considered as stunted and thin, respectively [31]. A single 24-h recall method was used to estimate feeding practice of children and the collected dietary information was transferred to dietary diversity score tool that consisted of seven food groups. Adequate dietary diversity was defined as proportion of children who received food made from four or more food groups in the previous 24-h [32]. Another variable, diarrhea was defined as school children who had three or more loose stools in $24 \mathrm{~h}$ in the past 2 weeks from the date of survey [33].

\section{Data processing and analysis}

Data were coded, cleaned, and entered in to Epi-Info version 3.5.3 and then exported to Statistical Package for Social Sciences (SPSS) software version 20 for further analysis. HAZ and BAZ were calculated using AnthroPlus software version 1.0.4 by the WHO-2007 growth reference standard. Therefore, stunting and thinness were considered as the outcome variables. In the binary logistic regression model, mathematically expressed as; $\ln (\mathrm{P} / 1-\mathrm{P})=\alpha+\beta \mathrm{x} P / 1-\mathrm{P}=\mathrm{e}^{\mathrm{a}+\mathrm{bx}}=$ Odds $\mathrm{d} / \mathrm{e}=\mathrm{e}^{\mathrm{a}+\mathrm{bx}}$ and Odds $\mathrm{d} / \mathrm{e}=\mathrm{e}^{\mathrm{a}}$ then OR $=\mathrm{e}^{\mathrm{a}+\mathrm{bx}} / \mathrm{e}^{\mathrm{a}}=\mathrm{e}^{\beta}=\ln (\mathrm{OR})=\beta$ for calculating odds ratio and $95 \% \mathrm{CI}=\mathbf{e}^{(\beta+1.96 \mathrm{SE} \beta)}$ [34]. Backward- stepwise multivariate analysis was used to elicit associated factors of stunting and thinness, separately. Effect size was expressed by odds ratio (OR) with $95 \%$ confidence interval. Probability value of type- 1 error less than 0.05 was considered statistically significant.

\section{Results}

A total of 848 school aged children (5-14 years) were included in the study with the response rate of $97.6 \%$. Two- third (61.4\%) of head of the household were females. Majority household heads were illiterate (42\%) and worked as farmers $(54.1 \%)$ (Table 1$)$. One-thirds of the study participants used protected source of water (67.1\%) for household consumption, and latrine was available in $66.6 \%$ of the households. The overall prevalence of stunting and thinness was $35.5 \%$ [(95\% CI: 32.3, 38.7)] and 9.9\% [95\% CI: 7.9, 11.9], respectively (Table 2).

Both bivariate and multivariate analyses were carriedout to identify the determinants of stunting and thinness. Primarily, analysis was done to examine the effect of explanatory variables on stunting. Accordingly, the result of bivariate analysis showed that age of the child, availability of latrine, hand washing practice, water treatment, sex and history of child diarrhea had $P$-value < $0.2^{1}$. Nevertheless, age of the child, availability of latrine and hand washing practice were significantly and independently associated with stunting. The likelihood of stunting was 1.58 times higher among children aged 1014 years $[\mathrm{AOR}=1.58,95 \% \mathrm{CI}: 1.17,2.12]$ compared to their counterparts. The lack of a toilet facility $[\mathrm{AOR}=$ 1.60; 95\%CI: 1.17, 2.20)] increased the odds of stunting by 1.60 times. Decreased odds of stunting were illustrated among school aged children who had had hand washing habit before eating (Table 3).

On the other hand, the bivariate analysis result of thinness revealed that child age, dietary diversity, age and occupation of the head of households had a $P$-value of $<$ 0.2 . However, in the multivariate analysis, only dietary diversity was significantly associated with thinness. Children who consumed diversified diet were found with $34 \%$ reduced odds of thinness $[\mathrm{AOR}=0.64 ; 95 \%$ CI 0.39 : 0.97)] (Table 4).

\section{Discussion}

This study explored stunting, thinness and associated factors among school aged children in Lay Armachiho district. The findings of this current study revealed high prevalence of stunting (35.5\%) and thinness (9.9\%) among school aged children. The magnitude of stunting in the current study is consistent with a study done in Egypt (34.2\%) [18] and Kenya (30.2\%) [35]. However, our finding was comparatively higher than a study conducted in Addis Ababa City, Ethiopia (19.6\%) [11], a study done in Durbete Town, Ethiopia (11.2\%) [10] and the study finding reported from Burkina Faso (8.8\%) [36]. The differences might be due to variations in place residence. The participants of the current study were majorly (66\%) rural inhabitants compared to the latter three studies. Poor health

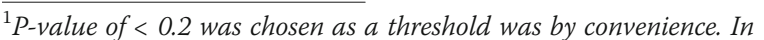
addition, majority of researchers used it and scholars recommended it as a cut-off point to control the possible effects of confounders during multivariate analysis.
} 
Table 1 Socio demographic characteristics of study participants in Lay Armachiho District, Northwest, Ethiopia, $2017(n=848)$

\begin{tabular}{lcc}
\hline Variables & Frequency & Percent (\%) \\
\hline $\begin{array}{l}\text { Sex of the child } \\
\text { Male }\end{array}$ & 399 & 47.1 \\
Female & 449 & 52.9 \\
& Age of the child in years & \\
$5-9$ & 510 & 60.1 \\
$10-14$ & 338 & 39.9 \\
& & \\
Orthodox & Religion & 97.8 \\
Muslim & 829 & 2.2 \\
& 19 & \\
Rural & Residence & 66.0 \\
Urban & 560 & 34.0
\end{tabular}

Sex of the household heads

$\begin{array}{lcc}\text { Male } & 327 & 38.6 \\ \text { Female } & 521 & 61.4 \\ & & \\ & \text { Age of the household heads } & \\ >=35 & 258 & 30.4 \\ 36-49 & 463 & 54.6 \\ 50-65 & 101 & 11.9 \\ >65 & 26 & 3.1\end{array}$

Marital status of the head of the households

$\begin{array}{lll}\text { Married } & 673 & 79.4 \\ \text { Divorced } & 114 & 13.4 \\ \text { Widowed } & 61 & 7.2\end{array}$

Relationship with the child

$\begin{array}{lll}\text { Mother } & 459 & 54.1 \\ \text { Father } & 269 & 31.7 \\ \text { Grandparent } & 90 & 10.6 \\ \text { Others }^{\mathrm{a}} & 30 & 3.5\end{array}$

Occupation of the head of the households

$\begin{array}{lll}\text { Merchant } & 136 & 16.0 \\ \text { Farmer } & 459 & 54.1 \\ \text { Governmental employed } & 67 & 7.9 \\ \text { Not employed } & 186 & 21.9\end{array}$

Child on education

$\begin{array}{lll}\text { No } & 98 & 11.6\end{array}$

$\begin{array}{lll}\text { Yes } & 750 & 88.4\end{array}$
Table 1 Socio demographic characteristics of study participants in Lay Armachiho District, Northwest, Ethiopia, $2017(n=848)$ (Continued)

\begin{tabular}{lcl}
\hline Variables & Frequency & Percent (\%) \\
\hline \multicolumn{3}{c}{ Educational level of the head of the households } \\
No schooling & 356 & 42 \\
Primary & 267 & 31.5 \\
Secondary & 225 & 26.5 \\
\hline
\end{tabular}

${ }^{\mathrm{a}}$ Sisters, brothers, aunts and uncle

care access, poor child feeding and caring practice are among a major problem in the rural part of Ethiopia [37].

This implies that unfair access and poor child feeding cause to inequalities in child health outcomes between rural and urban settlements [38].

In the current study, magnitude of thinness (9.9\%) was consistent with findings in West Ethiopia (13.2\%) [21] and southern Ethiopia (14\%) [17], Western region of Nepal (12\%) [39] and Burkina.

Faso (13.7\%) [36]. However, the finding was higher than that of study in Egypt (0.9\%) [18]. The discrepancy might be due to the difference in the livelihood of the population; agriculture and industry is the dominant economic sources in Egypt, traditional farming by using an ox is used in the Lay Armachiho district, where the current study took place. Given this information, children of the current study area may not have enough food which increases their risk of acute malnutrition.

In the multivariable analysis the odds of stunting were nearly 1.6 times higher among children aged $10-14$ years compared with those aged 5-9 years. Similar local findings were documented in Ethiopia [10,17]. This may be due to the fact that stunting is a chronic nutritional problem in which, once a child is stunted it difficult to reverse in the late childhood.

In addition, the odds of stunting were 1.6 times higher among school aged children with lack of availability of a latrine at home. Similar results were reported by other local studies $[40,41]$. In the absence of a latrine at home open defecation increases contamination of the household's environment [42]. In support of this evidence study from India confirmed that open defecation increases the likelihood of child stunting [43]. This is presumably related to ingestion of fecal microbes (parasites and bacteria) because of contamination of their finger with fecal matter while playing. This in turn predisposes children with repeated attack of diarrheal diseases which is an immediate cause of malnutrition mainly through malabsorption of nutrients and increased energy and micronutrient requirements [44]. Such explanation suggested the paramount importance of maintaining optimal hygiene and sanitation to curve child stunting. The finding of this study also illustrated the protective effect of hand washing habit of 
Table 2 Behavioral and households characteristics of study participants in Lay Armachiho District, northwest Ethiopia, 2017

\begin{tabular}{lll}
\hline Variables & Frequency & Percent (\%) \\
\hline Time to fetch water & & \\
$\leq 30$ min & 721 & 85.0 \\
$>30$ min & 127 & 15.0
\end{tabular}

Source of water

$\begin{array}{lll}\text { Protected } & 569 & 67.1 \\ \text { Unprotected } & 279 & 32.9\end{array}$

Water treatment

$\begin{array}{lll}\text { No } & 655 & 77.2 \\ \text { Yes } & 193 & 22.8\end{array}$

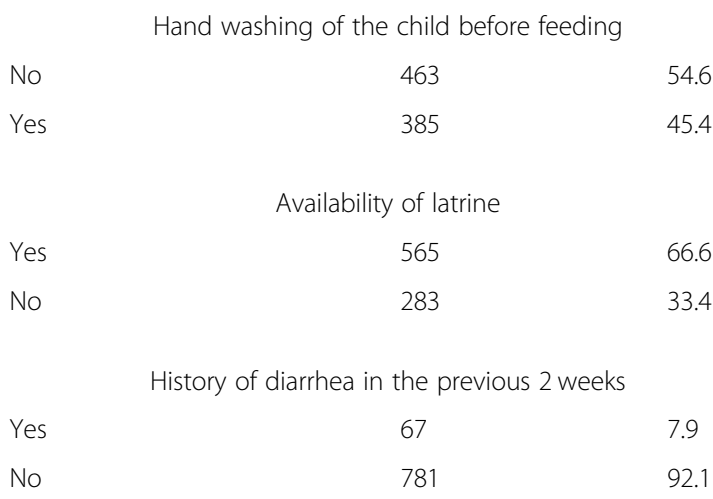

$\begin{array}{lcc} & \text { Dietary diversity } & \\ \text { Minimum diversity } & 334 & 39.5 \\ \text { Poor diversity } & 514 & 60.5\end{array}$

Food security status

\begin{tabular}{lcc} 
Secured & 661 & 77.9 \\
Mildly insecured & 108 & 12.7 \\
Moderately insecured & 52 & 6.1 \\
Severely insecured & 27 & 3.2 \\
& & \\
Yes & Stunting & \\
No & 301 & 35.5 \\
& 547 & 64.5 \\
Yes & Thinness & \\
No & 84 & 9.9 \\
\hline
\end{tabular}

children towards stunting. This report is also supported by the former study from India [45].

Finally, the findings of this study illustrated that dietary diversity, proxy indicator of micronutrient adequacy, of children was significantly associated with thinness. Children who consumed a diverse diet were found to
Table 3 Factors associated with stunting among the study participants in lay Armachiho District, northwest, Ethiopia

\begin{tabular}{|c|c|c|c|c|}
\hline \multirow[t]{2}{*}{ Variables } & \multicolumn{2}{|c|}{ Stunting } & \multirow[t]{2}{*}{$\operatorname{COR}(95 \% \mathrm{Cl})$} & \multirow[t]{2}{*}{$\mathrm{AOR}(95 \% \mathrm{Cl})$} \\
\hline & Yes (\#) & No (\#) & & \\
\hline \multicolumn{5}{|c|}{ Age of the child } \\
\hline $5-9$ years & 162 & 348 & 1 & 1 \\
\hline $10-12$ years & 139 & 199 & $1.50(1.13,1.98)$ & $1.58(1.17,2.12)^{*}$ \\
\hline \multicolumn{5}{|c|}{ Availability of latrine } \\
\hline No & 116 & 167 & $1.43(1.06,1.92)$ & $1.60(1.17,2.20)^{*}$ \\
\hline Yes & 185 & 380 & 1 & 1 \\
\hline \multicolumn{5}{|c|}{ Hand washing practice of the child before feeding } \\
\hline Yes & 151 & 308 & $0.79(0.59,1.04)$ & $0.67(0.49,0.91)^{*}$ \\
\hline No & 148 & 237 & 1 & 1 \\
\hline \multicolumn{5}{|c|}{ Water treatment } \\
\hline No & 242 & 413 & $1.33(0.94,1.88)$ & $1.24(0.86,1.81)$ \\
\hline Yes & 59 & 134 & 1 & 1 \\
\hline \multicolumn{5}{|c|}{ Child history of diarrhea in the previous 2 weeks } \\
\hline No & 272 & 509 & 1 & 1 \\
\hline Yes & 29 & 38 & $1.43(0.86,2.37)$ & $0.72(0.43,1.20)$ \\
\hline \multicolumn{5}{|l|}{ Sex of the child } \\
\hline Male & 133 & 266 & 1 & 1 \\
\hline Female & 168 & 280 & $1.20(0.95,1.59)$ & $1.21(0.90,1.61)$ \\
\hline
\end{tabular}

have a lower odds of thinness compared to those who had poorly diversified diet. This report is supported by previous findings elsewhere [17]. Children with a poorly diversified diet and inadequate micro-nutrient content have increased risk of impaired growth and development. This study showed the burden of undernutrition among school children in Lay Armachiho district where evidences are lacking.

\section{Conclusion}

In the Lay Armachiho district, one-third and one in every ten of school aged children were stunted and thin, respectively indicating that the problems are a serious public health concerns. Children age 10-14 years, lack of availability of a latrine at home and hand washing practices before eating were associated with stunting, while only dietary diversity was associated with thinness. Ensuring optimal latrine coverage and hand washing practices are the key to tackle undernutrition. Finally, this study also recommends enhancement of child dietary diversification.

\section{Limitations of the study}

This study tried to address a serious public health issue. However, some limitations, such as measurement errors could be committed while caring out anthropometric measurements. In addition, the study did not test the effect of 
Table 4 Factors associated with thinness among school aged children in Lay Armachiho, northwest, Ethiopia

\begin{tabular}{|c|c|c|c|c|}
\hline \multirow[t]{2}{*}{ Variables } & \multicolumn{2}{|c|}{ Thinness } & \multirow[t]{2}{*}{$\operatorname{COR}[95 \% \mathrm{Cl}]$} & \multirow[t]{2}{*}{ AOR $[95 \% \mathrm{Cl}]$} \\
\hline & Yes(\#) & $\mathrm{No}(\#)$ & & \\
\hline \multicolumn{5}{|l|}{ Age of the child } \\
\hline $5-9$ years & 42 & 468 & 1 & 1 \\
\hline 10-14 years & 42 & 296 & $1.58(0.96,2.48)$ & $1.58(0.98,2.48)$ \\
\hline \multicolumn{5}{|l|}{ Dietary diversity } \\
\hline Minimum diversity & 26 & 308 & $0.66(0.41,0.98)$ & $0.64(0.39,0.97)^{*}$ \\
\hline Poor diversity & 58 & 455 & 1 & 1 \\
\hline \multicolumn{5}{|c|}{ Occupation of the house hold heads } \\
\hline Merchant & 10 & 126 & 1 & 1 \\
\hline Farmer & 42 & 417 & $1.27(0.62,2.60)$ & $1.10(0.52,2.31)$ \\
\hline Governmental employed & 9 & 58 & $1.96(0.75,5.07)$ & $2.16(0.81,5.75)$ \\
\hline Not employed & 23 & 163 & $1.78(0.82,3.87)$ & $1.62(0.73,3.57)$ \\
\hline \multicolumn{5}{|l|}{ Age of the household heads } \\
\hline$>=35$ & 26 & 232 & 1 & 1 \\
\hline $36-49$ & 40 & 423 & $0.84(0.50,1.42)$ & $0.75(0.44,1.30)$ \\
\hline $50-65$ & 13 & 88 & $1.32(0.65,2.68)$ & $1.08(0.50,2.34)$ \\
\hline$>65$ & 5 & 21 & $2.13(0.74,6.11)$ & $2.00(0.67,5.96)$ \\
\hline
\end{tabular}

${ }^{*}=$ Statistically significant at $P$ value of $<0.05$

soil transmitted helminthes on risk of stunting. Due to the cross sectional nature of the study design it could not show the causal relationship between variables. Some of the events involved were happened in the past and hence recall bias can also be another limitation of this study. Furthermore, environmental and genetic factors were not considered in this study which may have an impact on our results.

\section{Abbreviations}

AOR: Adjusted odds ratio; BMI: Body mass index; Cl: Confidence interval; COR: Crude odds ratio; DDS: Dietary diversity score; SD: Standard deviation; WHO: World Health Organization

\section{Acknowledgements}

We would like to thank mothers for their willingness to participate in the study. Our appreciation will also go to the Lay Armachiho health bureau for material support.

\section{Authors' contributions}

EB, TD conceived the study, developed the tool, coordinated data collection, and carried out the statistical analysis and drafted the manuscript. EB, TD, SH, AM and MS conceived the study, participated in the statistical analysis, and drafted the manuscript. EB, TD, AM conceived the study and review the drafted manuscript. All authors read and approved the final manuscript.

\section{Funding}

The authors received no specific funding for this work.

\section{Availability of data and materials}

Due to ethical restrictions and privacy concerns, a dataset is available upon request from the corresponding author Mekonnen Sisay at mekudesu@gmail.com.

\section{Ethics approval and consent to participate}

The study was conducted in confirmation of ethical guidelines for research involving human subjects. Ethical clearance was obtained from the Institutional Review Board of the University of Gondar Institute of Public Health.
Communication with the different official administrators was made through formal letter obtained from the University of Gondar. Data was collected after the objective and aim of the study have been informed. Written consent was obtained from parents' or legal guardians' on a voluntary basis. The confidentiality of information was guaranteed by using code numbers rather than personal identifiers and by keeping the data locked. Participants were told to decline at any time if they feel uncomfortable, even after the interview has started.

\section{Consent for publication}

Not applicable

\section{Competing interests}

The authors declare that they have no competing interests.

\section{Author details}

Medical Ward, University of Gondar Comprehensive Specialized Hospital, Gondar, Ethiopia. ${ }^{2}$ Department of Health Education and Behavioral Sciences, Institute of Public Health, College of Medicine and Health Sciences, University of Gondar, Gondar, Ethiopia. ${ }^{3}$ Department of Human Nutrition, Institute of Public Health, College of Medicine and Health Sciences,

University of Gondar, Gondar, Ethiopia.

Received: 15 March 2019 Accepted: 23 August 2019

Published online: 02 September 2019

References

1. World Health Organization. Research to improve implementation and effectiveness of school health programmes, vol. 1. Geneva: WHO; 1996. p. 9-15.

2. Anonymous. WHO report life in the 21 st century - a vision for all. Geneva: WHO; 1998. p. 93.

3. Government of the Federal Democratic and Republic of Ethiopia: National Nutrition Program II. 2016-2020.

4. Bundy D, Burbano C, Grosh M, Gelli A, Jukes M, Drake L. Rethinking school feeding: social safety nets. Child development, and the education sector. Washington, DC: World Bank; 2009.

5. World Health Organization (WHO). Children schools and health; their nutrition and health in Kenya. WHO Global database on child growth and 
malnutrition; 2008. p. 17-20. Retrieved from www.schoolsandhealth.org on 24/1/2012

6. Onis MD, Onyango AW, Borghi E, Siyam A, Nishida C, Siekmann J. Development of a WHO growth reference for school-aged children and adolescents. Bull World Health Organ. 2007;85(9):660-7.

7. Morris SS, Cogill B, Uauy R. Maternal and child undernutrition 5: effective international action against undernutrition: why has it proven so difficult and what can be done to accelerate progress? Lancet. 2008;371(9612):608,

8. United nation systems. Standing committee for nutrition. School age children their health and nutrition. Number 25: ISSN; 2002. p. 1564-3743.

9. Frongillo EAJ. Causes and etiology of stunting. Am Soc Nutr Sci J Nutr. 1999;129:529-30.

10. Alelign T, Degarege A, Erko B. Prevalence and factors associated with undernutrition and anaemia among school children in Durbete town Northwest Ethiopia. Arch Public Health. 2015;73(1):34

11. Degarege $D$, Degarege A, Animut A. Undernutrition and associated risk factors among school age children in Addis Ababa, Ethiopia. BMC Public Health. 2015;15(1):375.

12. Partnership for Child Development. The anthropometric status of school children in five countries in the Partnership for Child Development. Proc Nutr Soc. 1998:57:149-58.

13. Center on Hunger, Poverty and Nutrition Policy. Statement on the link between nutrition and cognitive development in children. Medford: Tufts University School of Nutrition; 1995.

14. Moock PR, Leslie J. Childhood malnutrition and schooling in the Terai region of Nepal. J Dev Econ. 1986;20:33-52.

15. Grantham-McGregor S, Cheung YB, Cueto S, Glewwe P, Richter L, et al. Developmental potential in the first 5 years for children in developing countries. Lancet. 2007:369:60-70.

16. Herrador Z, Sordo L, Gadisa E, Moreno J, Nieto J, Benito A, Aseffa A, Cañavate C, Custodio E. Cross-sectional study of malnutrition and associated factors among school aged children in rural and urban settings of Fogera and Libo Kemkem districts, Ethiopia. PLoS One. 2014;9(9):e105880.

17. Wolde M, Berhan Y, Chala A. Determinants of underweight, stunting and wasting among schoolchildren. BMC Public Health. 2015;15:8.

18. Abdel Wahed WY, Hassan SK, Eldessouki R. Malnutrition and its associated factors among rural school children in Fayoum governorate, Egypt. J Environ Public Health. 2017:2017:1.

19. Mesfin F, Berhane $Y$, Worku A. Prevalence and associated factors of stunting among primary school children in Eastern Ethiopia. Nutr Diet Suppl. 2015;7:61-8.

20. Dekker LH, Mora-Plazas M, Marín C, Baylin A, Villamor E. Stunting associated with poor socioeconomic and maternal nutrition status and respiratory morbidity in Colombian schoolchildren. Food Nutr Bull. 2010;31(2):242-50

21. Mekonnen Z, Meka S, Zeynudin A, Suleman S. Schistosoma mansoni infection and undernutrition among school age children in Fincha'a sugar estate, rural part of West Ethiopia. BMC Res Notes. 2014;7(1):763.

22. State Minister of Health, Federal Democratic Republic of Ethiopia, The cost of HUNGER in Ethiopia, the social and economic impact of child undernutrition in Ethiopia, Addis Ababa, Ethiopia, 2009

23. Dedefo M, Zelalem D, Eskinder B, Assefa N, Ashenafi W, Baraki N, Tesfatsion MD, Oljira L, Haile A. Causes of death among children aged 5 to 14 years old from 2008 to 2013 in Kersa health and demographic surveillance system (Kersa HDSS), Ethiopia. PLoS One. 2016;11(6):e0151929.

24. Demissie S, Worku A. Magnitude and factors associated with malnutrition in children 6-59 months of age in pastoral community of Dollo Ado district, Somali region, Ethiopia. Sci J Public Health. 2013;1 (4):175-83.

25. Amare D, Negassie A, Tsegaye B, Assefa B, Ayenie B. Prevalence of undernutrition and its associated factors among children below five years of age in bure town, west Gojjam zone, Amhara National Regional State, Northwest Ethiopia. Adv Public Health. 2016;2016:1.

26. Ayana AB, Hailemariam TW, Melke AS. Determinants of acute malnutrition among children aged 6-59 months in public hospitals, Oromia region, West Ethiopia: a case-control study. BMC Nutrition. 2015;1(1):34.

27. Central Statistical Agency (CSA) [Ethiopia] and ICF. Ethiopia demographic and health survey 2016. Addis Ababa and Rockville: CSA and ICF; 2016.

28. Census 2007 Tables: Amhara Region Archived 2010-11-14 at the Wayback Machine.

29. Cogill B, Food, Project NTA. Anthropometric indicators measurement guide: food and nutrition technical assistance project, academy for educational development.2003.
30. WHO. Physical status: the use and interpretation of anthropometry: report of a WHO expert committee. WHO technical report series: World Health Organization.1995

31. World Health Organization, UNICEF: WHO child growth standards and the identification of severe acute malnutrition in infants and children: joint statement by the World Health Organization and the United Nations Children's Fund. 2009

32. World Health Organization: Indicators for assessing infant and young child feeding practices part 3: country profiles. 2010.

33. Glass RI, Parashar U, Patel M, Gentsch J, Jiang B. Rotavirus vaccines: successes and challenges. J Infect. 2014;68:S9-18.

34. Hosmer DW, Lemeshow S. Wiley series in probability and statistics. Applied logistics regression. 2nd ed; 2000.

35. Joshi HSGR, Joshi MC, et al. Determinants of nutritional status of school children a cross sectional study in the Western region of Nepal, Northeast India. NJIRM. 2011;2(1):10-5.

36. Daboné C, Delisle HF, Receveur O. Poor nutritional status of schoolchildren in urban and peri-urban areas of Ouagadougou (Burkina Faso). Nutr J. 2011; 10(1):34.

37. Central Statistical Authority [Ethiopia] and ORC Macro. Ethiopia demographic and health survey 2011. Addis Ababa: Ethiopia and Calverton; 2011

38. Siddiqi A, Hertzman E, Irwin LG, Hertzman C. Early child development: a powerful equalizer. Improving equity in health by addressing social determinants; 2012. p. 115-41.

39. Joshi HS, Gupta R, Joshi MC, Vipul M. Determinants of nutritional status of school children-a cross sectional study in the western region of Nepal. Natl J Integr Res Med. 2017;2(1):10-5.

40. Yetubie M, Haidar J, Kassa H, Fallon F. Socioeconomic and demographic factors affecting body mass index of adolescents students aged 10-19 in Ambo (a rural town) in Ethiopia. Int J Biomed Sci. 2010;6(4):321.

41. Derso T, Tariku A, Biks GA, Wassie MM. Stunting, wasting and associated factors among children aged 6-24 months in Dabat health and demographic surveillance system site: a community based cross-sectional study in Ethiopia. BMC Pediatr. 2017;17(1):96.

42. Curtis V, Cairncross S, Yonli R. Domestic hygiene and diarrhoea-pinpointing the problem. Tropical Med Int Health. 2000:5(1):22-32.

43. Spears D, Ghosh A, Cumming O. Open defecation and childhood stunting in India: an ecological analysis of new data from 112 districts. PLoS One. 2013;8(9):e73784.

44. Pruss-Ustun A, World Health Organization. Safer water, better health: costs, benefits and sustainability of interventions to protect and promote health. 2008.

45. Meshram II, Kodavanti MR, Chitty GR, Manchala R, Kumar S, Kakani SK Kodavalla V, Avula L, Ginnela Narsimhachary Veera B. Influence of feeding practices and associated factors on the nutritional status of infants in rural areas of Madhya Pradesh state, India. Asia Pac J Public Health. 2015;27(2): NP1345-61.

\section{Publisher's Note}

Springer Nature remains neutral with regard to jurisdictional claims in published maps and institutional affiliations.

Ready to submit your research? Choose BMC and benefit from:

- fast, convenient online submission

- thorough peer review by experienced researchers in your field

- rapid publication on acceptance

- support for research data, including large and complex data types

- gold Open Access which fosters wider collaboration and increased citations

- maximum visibility for your research: over $100 \mathrm{M}$ website views per year

At BMC, research is always in progress.

Learn more biomedcentral.com/submissions 